\title{
A Quantitative Assessment on Vulnerability to Poverty and Risk Management of Rural Farm Household in Northeastern of Thailand
}

\author{
Thitiwan Sricharoen
}

\begin{abstract}
This research presents a framework to analyze vulnerability to poverty of farm household in Northeastern of Thailand. Specific random samplings of 415 households are divided into 23 districts in Buri Ram province. The vulnerability to poverty analysis is done by feasible generalized least squares method. The rural headcount ratio in terms of household expected consumption less than poverty line is relatively high at $65.8 \%$. There are two groups of households, which are, high and low vulnerable households. The comparison of observed poverty status based on vulnerability index present that $75.2 \%$ of farm households are poor, whereas another $24.8 \%$ are non-poor.
\end{abstract}

Index Terms-Farm Household, Livelihood Strategies, Risk Management, Vulnerability to poverty.

\section{INTRODUCTION}

Economists have long used measures of poverty to summarize the well-being of less fortunate households in a population. Typically either income or consumption expenditures are measured over some relatively short period of time (e.g., a year), and these are regarded as some kind of proxy for the material well-being of the household. Policies often explicitly crafted to reduce these poverty measures. At the same time, economists have long recognized that a households sense of well-being depends not just on its average income or expenditures, but that risk plays an important role in determining welfare, particularly in households with fewer resources. To consider an extreme case, a household with very low expected consumption expenditures but with no chance of starving may will be poor, but they still might not wish to trade places with a household having a higher expected consumption but greater consumption risk. It seems desirable to have a measure of household welfare which takes into account both average expenditures as well as the risk households bear (Ligon and Schechter, 2002).

\section{The POVERTy IN THAILAND}

The poverty situation in Thailand is very important. People are poor and have the problem of income distribution. Figure 1 presents the income equality. The ratio of the share of national income going to the richest $20 \%$ of households in a

Manuscript received July 19, 2011; revised August 2, 2011. This work was supported in part by Faculty of Management Science, Khon Kaen University.

Thitiwan Sricharoen is with the Department of Economics, Faculty of Management Science, Khon Kaen University, Thailand, 40000 (e-mail: thitiwans@gmail.com). country to the share of the poorest $20 \%$ is a useful measure of inequality. Figures from the World Bank show that by this indicator many of the world's most unequal countries are in Latin America. In Colombia the incomes of the top fifth are nearly 25 times those of the bottom fifth. Most emerging Asian countries are less unequal: the incomes of the richest $20 \%$ of Chinese are about eight times those of the poorest $20 \%$. In Thailand, one of Asia's most unequal countries, the ratio is 15:1. Qatar's income per person is among the world's highest. But income is unequally distributed: the richest Qataris receive over 13 times as much as the poorest (The Economist, 2011).

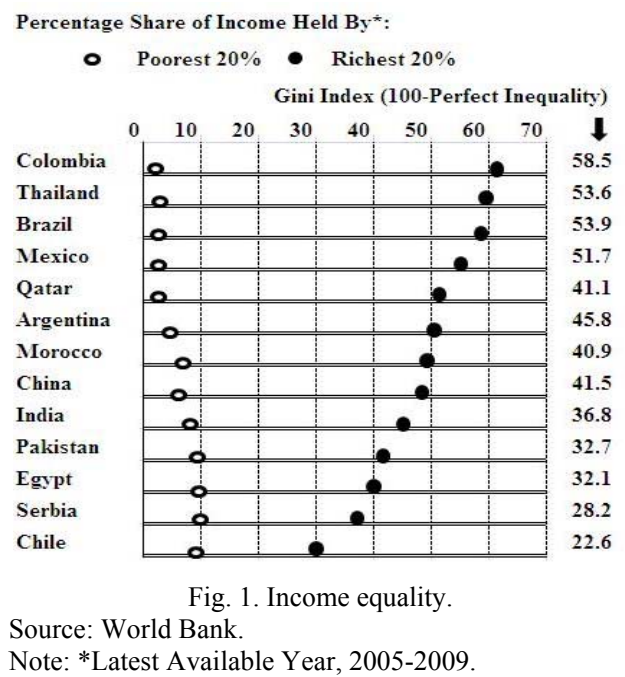

The perspective of the consequence of poverty is spread around Thailand, especially in the Northeast region. Farm households are vulnerable and fragile. The vulnerable households are taking the high risk, which cause them to be under the unsustainable livelihood to be falling into the poverty in the future. The method to identify the vulnerable households is important to identify which group of households should be under supervising in orderly. Therefore, the vulnerability measurements are so important.

Vulnerability must be defined relative to some benchmark. The natural benchmark would be vulnerability to poverty. Poverty should be considered in its various dimensions. Vulnerability to one dimension does not necessarily mean vulnerability to another. The lack of a "single" dimension for discussion should not be a problem, even in quantitative work. It is perfectly feasible to discuss in quantitative work vulnerability to poor education, to poor health and to income poverty as separate dimensions of vulnerability to poverty. Vulnerability is also forward-looking: it makes a statement about future poverty (Dercon, 2001). Furthermore, vulnerability is defined as ex-ante poverty. The vulnerability 
measurement is the method to calculate the probability of being poor in the next period or further in the future. Under this definition, it is not only poverty due to risk should be considered, it should be included those not expected to move out of poverty, those that will move permanently into poverty and those falling into poverty. Vulnerability measurement could include decomposition into who is most at risk and from which sources of risk. Therefore, vulnerability defines as the probability that a household will experience a future period of poverty. This sort of dynamic concern has behavioral implications separate from those of poverty. As a consequence, a measure that identifies vulnerable households is potentially quite valuable (Mansuri and Healy, 2000).

In the disentangling poverty and its determinants are illuminating for the policy makers and the relevance authorities, who work close to the target group. For policy makers, concerned with the issues of vulnerability, this seems a large agenda. Many of these issues require much more research, close interaction between academics, policy makers, households, and other social groups.

Poverty is one of the chronic social problems of Thailand, and both the former and current government has set different strategies to eradicate it. Various interventions have been undertaken to strengthen the grassroots economy, as well as reduce the incidence of poverty. However, it is difficult to solve these problems due to the complexity of the economy and society, and especially the vulnerability of the household itself. There is widespread poverty in Thailand, and many households suffer spells of chronic and transient poverty. Also, the ability of households to cross a given income threshold or poverty line is very small.

In Thailand, the poverty line has been utilized for assessing and monitoring the poverty situation. The average for the whole kingdom of Thailand's poverty line in 2009 was at $1,586 \mathrm{Baht}^{1}$ (\$51.66) per capita per month. When comparing poverty situation between regions, it was found that Northeastern of Thailand's the region where contained a great number of the poor higher than other regions from the past to present. This region is the target region to implement poverty reduction policy.

Data from table I present the average income per household in 2007. Average household income of overall country was at 18,660 Baht (\$607.82) per year. Household in Bangkok metropolitan area, except Nakhon Pathom and Samut Sakhon, had the highest income, while northeast region household had the lowest income.

TABLE I. The Average InCOMES PER HouseHold IN 2007 Classified BY REGION

\begin{tabular}{|c|c|}
\hline Region & $\begin{array}{c}\text { Average } \\
\text { income per } \\
\text { household in } \\
2007 \text { (Baht) }\end{array}$ \\
\hline Overall country & 18,660 \\
\hline Bangkok, Nonthaburi, Pathum Thani and \\
Samut Prakan province & 35,007 \\
\hline South region & 19,716 \\
\hline Central region & 18,932 \\
\hline North region & 13,568 \\
\hline Northeast region & $\mathbf{1 2 , 9 9 5}$ \\
\hline Source: NSO (2007)
\end{tabular}

Source: NSO (2007)

Exchange rate: $1 \$=30.7$ Baht; On February 10, 2011.
Figure 2 presents the average number of poor people in Northeastern of Thailand. Surin, Buri Ram and Si Sa Ket provinces have the highest number of the poor between 2000 and 2007. In the year of 2007, there was the greatest number of the poor in Si Sa Ket province, following by Buri Ram, Surin and other provinces respectively.

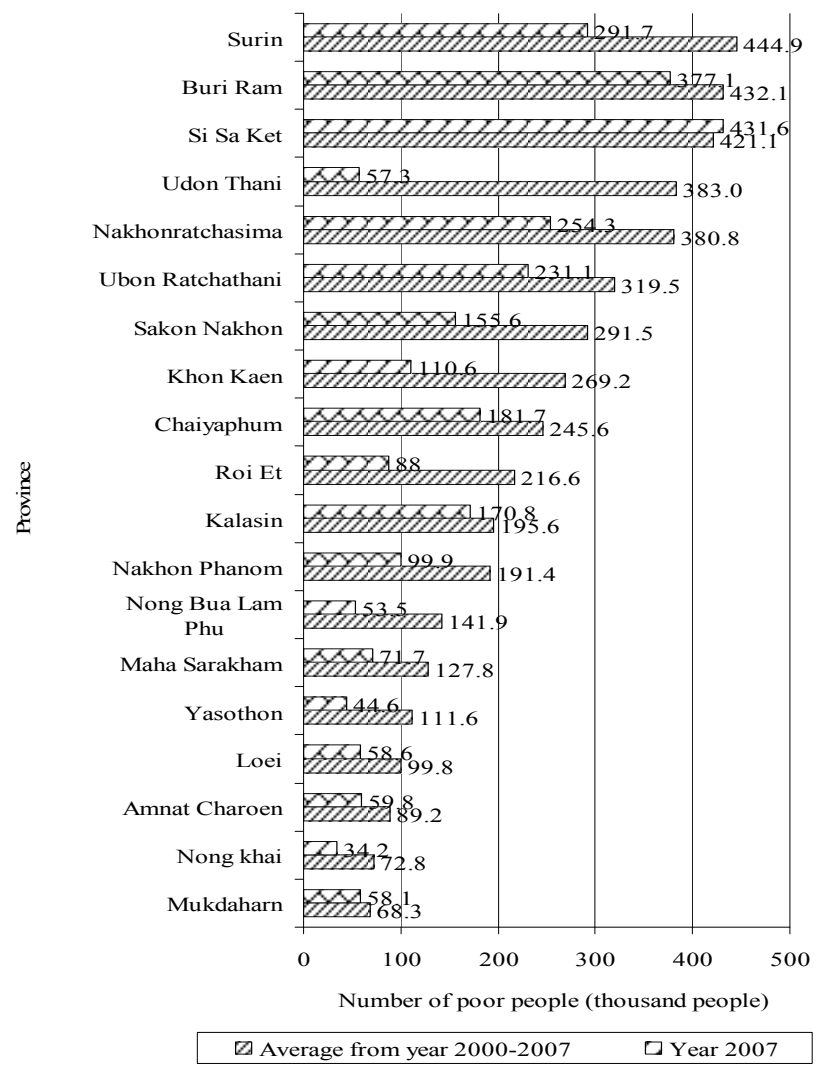

Fig. 2. Average numbers of poor people in northeastern of Thailand. Source: Own calculation. Data from NESDB., 2008: p. 7.

By all estimates and available definitions, the poverty of household in Northeastern of Thailand is strikingly widespread and pervasive. In solving poverty of Thailand, the policy makers need to understand the poverty in multidimensional views and solve the poverty problem direct to the target group. It is not only to help only people who are in the poverty group but it covers the people who are expecting to fall in poverty in the near future or in the vulnerability group.

\section{Methodologies}

This research presents a framework to describe and analyze risk and vulnerability to poverty of rural farm household in Northeastern of Thailand. Specific random sampling technique is used in the selection of 415 households, which are divided into 23 districts in Buri Ram province. It discusses the measurement of vulnerability to poverty, with an emphasis on quantitative techniques. In this research, the feasible generalized least square applies to analyze the vulnerability to poverty of household.

The key to estimating a household's vulnerability to poverty is to obtain an estimate of the household's variance of consumption expenditure. A reliable estimate of consumption expenditure variance can be obtained from panel data collected over a sufficiently long period. However, 
as noted by Jalan and Martin (2003), most of the available standard data sources are based on a 'single visit' (cross-sectional) household survey and cannot be used for this purpose. Hence, there is a need to develop a method for estimation household consumption expenditure variance from cross-section data. This, however, obviously requires relatively strong assumptions about the stochastic process generation consumption (Suryahdi and Sumarto, 2001).

Chaudhuri, Jalan, and Suryahadi (2002) has developed a methodology to estimate vulnerability of a household to poverty using cross sectional data by using Philippines data for 1997. Chaudhuri and Datt (2001) find that they are able to predict which households will be poor in 1998. Suryahdi and Sumarto (2001) have adopted this methodology to identify households that are vulnerable to poverty and to identify the chronic poor in Indonesia. They do this by making use of information on vulnerability to poverty based on current consumption, the estimated degree of vulnerability and the estimated expected consumption. Five categories of households are developed. These are poor, non-poor, high vulnerability to poverty, low vulnerability to poverty and the total vulnerable group. The total vulnerable group includes non-poor households. These are households that are currently non-poor but are expected to become poor in the future. The critical vulnerability level that is adopted in their study is 0.5 . A household is described as being highly vulnerable to poverty if the probability that it will be poor is equal to or greater than 0.5 (Abena, Kojo, and Senadza, 2004).

The vulnerability level of a household at time $t$ is the probability that it will be consumption poor at time $\mathrm{t}+1$ thus:

$$
V_{h t}=\operatorname{Pr}\left(C_{h t+1} \leq z\right)
$$

where $\mathrm{C}_{\mathrm{ht}+1}$ is the household's consumption expenditure at time $\mathrm{t}+1$ and $\mathrm{z}$ is the poverty line.

Consumption expenditure is determined by observable household characteristics $X_{h}$, the state of the economy at time t $\mathrm{S}_{\mathrm{t}}$, unobserved time invariant household level effects $\alpha_{h}$, and any idiosyncratic factors that contribute to differential welfare outcomes for households that are otherwise observationally equivalent, $\mathcal{E}_{h t}$. Thus

$$
C_{h t}=c\left(X_{h}, \beta_{t}, \alpha_{h}, \varepsilon_{h t}\right)
$$

With cross-sectional data there is not enough information to include changes in the structure of the economy and idiosyncratic shocks to household. Thus, we begin by assuming that the stochastic process generation the consumption of a household $h$ is given by:

$$
{ }^{L n c}{ }_{h}=X_{h} \beta+\varepsilon_{h}
$$

where $c_{h}$ is per capita consumption expenditure, $X_{h}$ represents a bundle of observable household characteristics such as household size, education of household head, etc., $\beta$ is a vector of parameters, and $\varepsilon_{h}$ is a mean-zero disturbance term that captures idiosyncratic factors (shocks) that contribute to different per capita consumption levels for households that are otherwise observationally equivalent.
In addition the variance of $\varepsilon_{h t}$ is allowed to depend on observable household characteristics. We assume that the variance of $\mathcal{E}_{h}$ is given by:

$$
\sigma_{\mathcal{E}, h}^{2}=X_{h} \theta
$$

Estimates of $\beta$ and $\theta$ are obtained using a three step feasible generalized least squares procedure. We estimate equation (4) using an ordinary least squares (OLS) procedure. We use the estimated residuals from equation (4) to estimate:

$$
\hat{\varepsilon}^{2} O L S, h=X h^{\theta+} \eta_{h}
$$

The OLS estimate, $\hat{\theta}_{O L S}$ is then used to transform as:

$$
\frac{\hat{\varepsilon}^{2} O L S, h}{x_{h} \hat{\theta} O L S}=\left(\frac{X h}{X_{h} \hat{\theta} O L S}\right) \theta+\frac{\eta_{h}}{X_{h} \hat{\theta} O L S}
$$

This transformed equation is estimated using OLS to obtain an asymptotically efficient FGLS estimate, $\hat{\theta} F G L S$. Note that $X_{h} \hat{\theta} F G L S$ is a consistent estimate of $\sigma_{e, h}^{2}$, the variance of the idiosyncratic component of household consumption. Then, we transform equation (6) as below:

$$
\frac{\ln c_{h}}{\sqrt{X_{h} \hat{\theta} F G L S}}=\left(\frac{X_{h}}{\sqrt{X_{h} \hat{\theta} F G L S}}\right) \beta+\frac{\varepsilon_{h}}{\sqrt{X_{h} \hat{\theta} F G L S}}
$$

OLS estimation of equation (7) yields a consistent and asymptotically efficient estimate of $\beta$. The standard error of the estimated coefficient, $\hat{\beta} F G L S$, can be obtained by dividing the reported standard error by the standard error of the regression.

Using the estimates and that we obtain we are able to directly estimate expected log consumption:

$$
\hat{E}\left[\ln c_{h} \mid X_{h}\right]=x_{h} \hat{\beta}
$$

And the variance of log consumption for each household $h$ :

$$
\hat{V}\left[\ln c_{h} \mid X_{h}\right]=\hat{\sigma} \varepsilon, h=X_{h} \hat{\theta}
$$

By assuming that consumption is log-normally distributed, we are then able to use these estimates to form an estimate of the probability that household with the characteristics, $X_{h}$, will be poor, i.e, to estimate the household's vulnerability level. Letting $\phi($.$) denotes the cumulative density of the$ standard normal.

The estimates of $\beta$ and $\theta$ are used to obtain estimates of expected log consumption and the variance of $\log$ consumption for each household. The estimates of $\log$ consumption and the variance of log consumption are used to form an estimate of the probability that a household with characteristics $X_{h}$ will be poor, i.e. the household's 
vulnerability level.

$$
\hat{V} h=\hat{\operatorname{Pr}}\left(\ln c_{h}<\ln c \mid X_{h}\right)=\phi\left[\frac{\ln \mathrm{c}-X_{h} \hat{\beta}}{\sqrt{X_{h} \hat{\theta}}}\right]
$$

To deal with measurement error it is recommended that the estimates are applied at a disaggregated level.

As the available data for the estimation of vulnerability consist of a single cross-section, identifying the household characteristics that are associated with vulnerability necessitates making strong assumptions about the stochastic process that generates consumption (Chaudhuri, 2000). Probably the most important and strongest identifying assumption is that cross-sectional variance can be used to estimate inter-temporal variance. Most likely cross-sectional variance can explain a part of inter-temporal variance, mostly due to idiosyncratic components or cluster-specific shocks. However, the model will miss the impact of inter-temporal or aggregate (household-invariant but time-variant) shocks. In other words, the model will probably produce good estimates of vulnerability for the situations where the distribution of risks and the risk-management instruments are similar in all periods of time. As there is probably some error in the measurement of consumption, this may have resulted in significant overestimation of the variance of consumption, and thus of vulnerability. An advantage of the estimation strategy used in this paper - using a FGLS approach to estimate the variance of the idiosyncratic component of household consumption - is that it yields a consistent estimate of the true variance of consumption even when consumption is measured with error unless the measurement error varies systematically with some household characteristics (Tesliuc and Lindert, 2002).

The data of household surveys in the end of the year of 2009 were used to estimate vulnerability at household level. The method (feasible generalized least squares-FGLS) is employed to determine how log consumption impacts the welfare status of households in the research area. It is recognized that one of the basic assumptions of ordinary least square (OLS) is that the error term must have a mean zero and constant variance, and that once this constant variance assumption is violated, there is bound to be heteroscedasticity. The relaxation of the constant variance assumption according to Chaudhuri (2000) is a method of determining how the variance of the error term (i.e., now a measure of $\log$ consumption) impacts overall well-being (proxies by expenditure on food and non-food items) (Oluwatayo, 2004).

An advantage of the estimation strategy used in this research - using a FGLS approach to estimate the variance of the idiosyncratic component of household consumption - is that it yields a consistent estimate of the true variance of consumption even when consumption is measured with error unless the measurement error varies systematically with some household characteristic(s). It may in fact be the case that measurement error is correlated with some observable characteristic of the household. For instance, rural households derive a larger share of their food consumption from their own production than urban households evaluated at imputed (not reported or observed) prices. If this is the case, it is possible to obtain unbiased estimators of consumption variance by estimating separate models for rural and urban areas. Concerns about systematic measurement error are another reason for estimating separate models at as disaggregated a level as possible (Tesliuc and Lindert, 2002).

\section{QuAlitative AND QuANTITATIVE ASSESSMENT ON VULNERABILITY TO POVERTY}

In brief of household characteristics, average age of the household heads is at 52 years old. Most of household heads are male at $80.48 \%$. Total populations within the survey of 415 households are 2,047 persons, with an average of 5 persons per household. It is amount of $2.89 \%$ of all household has an inability person in family. According to the education of household, most household speak Thai with $56.87 \%$. The rest language uses are Lao and Cambodia with $28.43 \%$ and $14.7 \%$ respectively. Most household heads graduate primary school accounts for $61.93 \%$. Agriculture is the main occupation of household head, account for $71.08 \%$. The next occupation is general contractor, accounts for $13.25 \%$. The rests are trading, government officer, and state enterprise officer. Each household has an average income 15,252 Baht (\$496.8) per month per household. It is $86.54 \%$ of income comes from farm work.

According to the demand on government assistance, household has the highest demand level on agricultural product price guarantee or crop insurance, following by the financial aid policy, fertilizer price guarantee, job creation policy, irrigation system, village fund and land allocation policy, drug and gamble reduction, and road construction, respectively.

The result on vulnerability to poverty analysis is done by FGLS method. It is employed to determine how log consumption impacts the welfare status of households in the research area. It is recognized that one of the basic assumptions of ordinary least square (OLS) is that the error term must have a mean zero and constant variance, and that once this constant variance assumption is violated, there is bound to be heteroscedasticity (Chaudhuri, 2000).The relaxation of the constant variance assumption is a method of determining how the variance of the error term (i.e., now a measure of $\log$ consumption) impacts overall well-being (proxies by expenditure on food and non-food items) (Oluwatayo, 2004).

The results of the model for the log consumption equation and variance of the log consumption (OLS) are shown in Table II. Upon subjecting the data to the analysis, the first stage of the OLS reveals that $61.17 \%$ of the variation in log consumption (a measure of well-being) can be explained by the following factors: household size, household size square, aged dependency ratio, family member: bachelor education and above, number of children attend the school, unemployed household head, monetary assets, tangible asset value, ratio of rent of total expenditure, drought in the future, number of last year risk occurred (2009), prolong sickness of household head (2009), chronic disease of other working family member (2009), flood (2009). The rest, 38.83\%, can be attributed to the disturbance term.

The low $\mathrm{R}^{2}$ value is not uncommon, and is due to the measurement error (from unobserved and omitted variables) associated with the use of cross-sectional data in 
consumption studies. However, this measurement error indirectly accounts for the importance of the disturbance term, a variable capturing idiosyncratic factors (which includes risk associated with income) (Oluwatayo, 2004). All the variables included in the analysis have some influence on household well-being. For example, household size, aged dependency ratio, unemployed household head, ratio of rent of total expenditure, drought, which household expect to encounter in the future and flood (2009) have a negative influence on the consumption expenditure of households in the study area.

Generally, most of the model's coefficients (log consumption and variance of log consumption) come up with expected signs. In all samples, family members who have bachelor education and above, number of children attend the school, monetary assets, tangible asset value, number of last year risk occurrence, prolong sickness of household head (2009), chronic disease of other working family member (2009) are positively significant in explaining welfare in the research area.

For instance, a strong relationship is apparent between log consumption and chronic disease of other working family member (2009), whereby the household which has chronic disease of other working family members have a positive effect on log consumption. An increase in chronic disease of other working family member leads to an increase in log consumption of 1.13 Baht. Households with a high number of chronic diseases of other working family members have higher consumption than households with no family members who get illness. This example is as same as the relationship between log consumption and prolongs sickness of household head during 2008-2009.

On the other hand, flood (2009) also has a strong relationship with log consumption, but in the negative direction. An increase of the ruin of flood leads to a decrease in $\log$ consumption of 0.95 Baht. Households, which encounter flood experience, have less consumption than households, which not encounter flood problem. In the same direction, drought, which household expect that it will occur in the future has a strong relationship with log consumption in the opposite direction. An increase of the drought situation that household expects to encounter in the future lead to a decrease in log consumption of 0.79 Baht. In research area, households are hit by the drought risk almost every year. Households, which expect that the drought may happen again in the future, have low present consumption and save it for future.

TABLE II. MODEL For ESTIMATING VULNERABILITY TO POVERTY By OLS

\begin{tabular}{|c|c|c|c|c|}
\hline & Total & & & \\
\hline \multirow[t]{2}{*}{ Variable } & OLS & & & \\
\hline & $\log (\mathrm{ctn})$ & $\mathrm{P}>|\mathrm{t}|$ & Var (ctn) & $\mathrm{P}>|\mathrm{t}|$ \\
\hline \multirow[t]{2}{*}{ Household size } & -.3895956 & 0.000 & -.040889 & 0.871 \\
\hline & $(.058235)$ & & $(0.252414)$ & \\
\hline \multirow[t]{2}{*}{$\begin{array}{l}\text { Household size } \\
\text { square }\end{array}$} & .018846 & 0.000 & .001183 & 0.955 \\
\hline & $(.004798)$ & & $(0.020796)$ & \\
\hline \multirow[t]{2}{*}{$\begin{array}{l}\text { Aged dependency } \\
\text { ratio }\end{array}$} & -.002240 & 0.000 & .004345 & 0.054 \\
\hline & $(.000518)$ & & $(0.002245)$ & \\
\hline \multirow[t]{2}{*}{$\begin{array}{l}\text { Family member: } \\
\text { Bachelor education } \\
\text { and above }\end{array}$} & .117383 & 0.003 & .405169 & 0.016 \\
\hline & $(.038692)$ & & $(0.167705)$ & \\
\hline
\end{tabular}

\begin{tabular}{|c|c|c|c|c|}
\hline \multirow[t]{2}{*}{$\begin{array}{l}\text { Number of children } \\
\text { attend the school }\end{array}$} & .119753 & 0.000 & .188690 & 0.130 \\
\hline & $(.028666)$ & & $(0.124251)$ & \\
\hline \multirow[t]{2}{*}{$\begin{array}{l}\text { Unemployed } \\
\text { household head }\end{array}$} & -.762958 & 0.005 & -1.570195 & 0.179 \\
\hline & $(.269356)$ & & $(1.167495)$ & \\
\hline \multirow[t]{2}{*}{ Monetary assets } & $3.35 \mathrm{e}-07$ & 0.000 & $-8.70 \mathrm{e}-09$ & 0.977 \\
\hline & $(7.05 \mathrm{e}-08)$ & & $(3.06 \mathrm{E}-07)$ & \\
\hline \multirow[t]{2}{*}{ Tangible asset value } & $1.09 \mathrm{e}-07$ & 0.001 & $4.50 \mathrm{e}-08$ & 0.755 \\
\hline & $(3.32 \mathrm{e}-08)$ & & (1.44E-07) & \\
\hline \multirow[t]{2}{*}{$\begin{array}{l}\text { Ratio of rent of total } \\
\text { expenditure }\end{array}$} & -.014048 & 0.000 & .011009 & 0.190 \\
\hline & $(.001933)$ & & $(0.008377)$ & \\
\hline \multirow[t]{2}{*}{ Drought, future } & -.795083 & 0.000 & 0.739832 & 0.217 \\
\hline & $(.138074)$ & & $(0.598469)$ & \\
\hline \multirow[t]{2}{*}{$\begin{array}{l}\text { Number of last year } \\
\text { risk occurrence }\end{array}$} & .049289 & 0.009 & 0.105181 & 0.198 \\
\hline & $(.018816)$ & & $(0.081556)$ & \\
\hline \multirow[t]{2}{*}{$\begin{array}{l}\text { Prolong sickness of } \\
\text { household head } \\
\text { (2009) }\end{array}$} & .553348 & 0.017 & 0.906512 & 0.365 \\
\hline & $(.230543)$ & & $(0.999264)$ & \\
\hline \multirow[t]{2}{*}{$\begin{array}{l}\text { Chronic disease of } \\
\text { other working family } \\
\text { member(2009) }\end{array}$} & 1.12685 & 0.000 & -0.54565 & 0.391 \\
\hline & $(.146733)$ & & $(0.635998)$ & \\
\hline \multirow[t]{2}{*}{ Flood (2009) } & -.953918 & 0.000 & -0.83014 & 0.462 \\
\hline & $(.260161)$ & & $(1.127639)$ & \\
\hline \multirow[t]{2}{*}{ Constant } & 11.3390 & 0.000 & -1.76468 & 0.203 \\
\hline & $(.319388)$ & & $(1.384353)$ & \\
\hline Observation & 415 & & 415 & \\
\hline R-squared & 0.6117 & & 0.0506 & \\
\hline Prob (F) & 0.000 & & 0.000 & \\
\hline
\end{tabular}

Source: Own calculation.

Note: $\log (\mathrm{ctn})=\log$ of consumption.

Var $(\mathrm{ctn})=$ Variance of consumption.

Standard errors are in parenthesis.

TABLE III. MODEL For ESTIMATING VULNERABILITY TO POVERTY BY

\begin{tabular}{|c|c|c|c|c|}
\hline \multicolumn{5}{|c|}{ FGLS } \\
\hline & Total & & & \\
\hline \multirow[t]{2}{*}{ Variable } & FGLS & & & \\
\hline & $\begin{array}{l}\log \\
\text { (ctn) }\end{array}$ & $\mathrm{P}>|\mathrm{z}|$ & Var (ctn) & $\mathrm{P}>|\mathrm{t}|$ \\
\hline \multirow[t]{2}{*}{$\begin{array}{l}\text { Household } \\
\text { size }\end{array}$} & $\begin{array}{c}0.70766 \\
1\end{array}$ & 0.000 & $\begin{array}{c}0.26259 \\
3\end{array}$ & 0.000 \\
\hline & $\begin{array}{c}(0.0987 \\
26)\end{array}$ & & $\begin{array}{c}(0.00810 \\
2)\end{array}$ & \\
\hline \multirow[t]{2}{*}{$\begin{array}{l}\text { Household } \\
\text { size square }\end{array}$} & $\begin{array}{c}-0.0635 \\
12\end{array}$ & 0.000 & $\begin{array}{c}-0.02222 \\
3\end{array}$ & 0.000 \\
\hline & $\begin{array}{c}(0.0084 \\
01)\end{array}$ & & $\begin{array}{c}(0.00068 \\
9)\end{array}$ & \\
\hline \multirow[t]{2}{*}{$\begin{array}{l}\text { Aged } \\
\text { dependency } \\
\text { ratio }\end{array}$} & $\begin{array}{c}-0.0012 \\
21\end{array}$ & 0.238 & $\begin{array}{c}-0.00015 \\
4\end{array}$ & 0.071 \\
\hline & $\begin{array}{c}(0.0010 \\
34)\end{array}$ & & $\begin{array}{c}(0.00008 \\
5)\end{array}$ & \\
\hline \multirow{2}{*}{$\begin{array}{l}\text { Family } \\
\text { member: } \\
\text { Bachelor } \\
\text { education and } \\
\text { above }\end{array}$} & $\begin{array}{c}0.06170 \\
2\end{array}$ & 0.425 & $\begin{array}{c}0.00604 \\
1\end{array}$ & 0.342 \\
\hline & $\begin{array}{c}(0.0773 \\
29)\end{array}$ & & $\begin{array}{c}(0.00634 \\
6)\end{array}$ & \\
\hline \multirow{2}{*}{$\begin{array}{l}\text { Number of } \\
\text { children } \\
\text { attend the } \\
\text { school }\end{array}$} & $\begin{array}{c}0.09608 \\
4\end{array}$ & 0.094 & $\begin{array}{c}0.01844 \\
9\end{array}$ & 0.000 \\
\hline & $\begin{array}{c}(0.0573 \\
24)\end{array}$ & & $\begin{array}{c}(0.00470 \\
4)\end{array}$ & \\
\hline
\end{tabular}




\begin{tabular}{|c|c|c|c|c|}
\hline \multirow[t]{2}{*}{$\begin{array}{l}\text { Unemployed } \\
\text { household } \\
\text { head }\end{array}$} & $\begin{array}{c}7.42042 \\
2\end{array}$ & 0.000 & $\begin{array}{c}3.74789 \\
8\end{array}$ & 0.000 \\
\hline & $\begin{array}{c}(0.2787 \\
56)\end{array}$ & & $\begin{array}{c}(0.02287 \\
5)\end{array}$ & \\
\hline \multirow[t]{2}{*}{$\begin{array}{l}\text { Monetary } \\
\text { assets }\end{array}$} & $\begin{array}{c}0.00000 \\
1\end{array}$ & 0.000 & $\begin{array}{c}0.00000 \\
0\end{array}$ & 0.000 \\
\hline & $\begin{array}{c}(0.0000 \\
00)\end{array}$ & & $\begin{array}{c}(0.00000 \\
0)\end{array}$ & \\
\hline \multirow[t]{2}{*}{$\begin{array}{l}\text { Tangible } \\
\text { asset value }\end{array}$} & $\begin{array}{c}0.00000 \\
0\end{array}$ & 0.101 & $\begin{array}{c}0.00000 \\
0\end{array}$ & 0.000 \\
\hline & $\begin{array}{c}(0.0000 \\
00)\end{array}$ & & $\begin{array}{c}(0.00000 \\
0)\end{array}$ & \\
\hline \multirow[t]{2}{*}{$\begin{array}{l}\text { Ratio of rent } \\
\text { of total } \\
\text { expenditure }\end{array}$} & $\begin{array}{c}-0.0101 \\
06\end{array}$ & 0.009 & $\begin{array}{c}-0.00199 \\
5\end{array}$ & 0.000 \\
\hline & $\begin{array}{c}(0.0038 \\
60)\end{array}$ & & $\begin{array}{c}(0.00031 \\
7)\end{array}$ & \\
\hline \multirow[t]{2}{*}{$\begin{array}{l}\text { Drought, } \\
\text { future }\end{array}$} & $\begin{array}{c}-0.9409 \\
89\end{array}$ & 0.001 & $\begin{array}{c}-0.20749 \\
6\end{array}$ & 0.000 \\
\hline & $\begin{array}{c}(0.2760 \\
61)\end{array}$ & & $\begin{array}{c}(0.02265 \\
4)\end{array}$ & \\
\hline \multirow[t]{2}{*}{$\begin{array}{l}\text { Number of } \\
\text { last year risk } \\
\text { occurrence }\end{array}$} & $\begin{array}{c}0.00445 \\
9\end{array}$ & 0.905 & $\begin{array}{c}-0.00381 \\
6\end{array}$ & 0.216 \\
\hline & $\begin{array}{c}(0.0375 \\
52)\end{array}$ & & $\begin{array}{c}(0.00308 \\
2)\end{array}$ & \\
\hline \multirow{2}{*}{$\begin{array}{l}\text { Prolong } \\
\text { sickness of } \\
\text { household } \\
\text { head (2009) }\end{array}$} & $\begin{array}{c}0.72325 \\
7\end{array}$ & 0.117 & $\begin{array}{c}0.14318 \\
6\end{array}$ & 0.000 \\
\hline & $\begin{array}{c}(0.4610 \\
45)\end{array}$ & & $\begin{array}{c}(0.03783 \\
4)\end{array}$ & \\
\hline \multirow[t]{2}{*}{$\begin{array}{l}\text { Chronic } \\
\text { disease of } \\
\text { other } \\
\text { working } \\
\text { family } \\
\text { member } \\
(2009)\end{array}$} & $\begin{array}{c}1.35703 \\
3\end{array}$ & 0.000 & $\begin{array}{c}0.30002 \\
8\end{array}$ & 0.000 \\
\hline & $\begin{array}{c}(0.2932 \\
16)\end{array}$ & & $\begin{array}{c}(0.02406 \\
2)\end{array}$ & \\
\hline \multirow[t]{2}{*}{ Flood (2009) } & $\begin{array}{c}-1.1648 \\
53\end{array}$ & 0.025 & $\begin{array}{c}-0.24256 \\
4\end{array}$ & 0.000 \\
\hline & $\begin{array}{c}(0.5202 \\
51)\end{array}$ & & $\begin{array}{c}(0.04269 \\
3)\end{array}$ & \\
\hline \multirow[t]{2}{*}{ Constant } & No & & No & \\
\hline & constant & & constant & \\
\hline Observation & 415 & & 415 & \\
\hline R-squared & & & 0.9996 & \\
\hline Prob (F) & 0.000 & 0.000 & 0.000 & 0.000 \\
\hline $\begin{array}{l}\text { Source: Own } \\
\text { Note: Log } \\
\text { Var }(\mathrm{ctn})=\mathrm{Va}\end{array}$ & $\begin{array}{l}\text { lation. } \\
=\text { Log o } \\
\text { ce of col }\end{array}$ & mption & & \\
\hline
\end{tabular}

The results of the regression model by FGLS are demonstrated in Table III, which presents the determinants of vulnerability to poverty by FGLS and variance of consumption. The signs of the coefficients indicate that number of last year risk occurrence has a positive impact on $\log$ consumption but a negative impact on variance of consumption.

Household size square, aged dependency ratio, ratio of rent of total expenditure, drought in the future, flood in 2009 have a negative impact on log consumption, as well as on variance of consumption. When households pay a high rent on land, it causes them have less of money left for the other consumption items. If the households are attacked by natural risks, like drought or flood, it will as the result of crop loss, which is probably difficult for them to smooth consumption.
Household size, family member: Bachelor education and above, number of children attend the school, unemployed household head, monetary assets, tangible asset value, prolong sickness of household head in 2009 and chronic disease of other working family member in 2009 have a tendency to increase log consumption and also to increase consumption variance. For example, if households have more monetary assets, they will have more ability to consume and have enough assets to smooth their consumption during the difficult time. Therefore, households may either sell the assets or rent them out. Moreover, the illness incidence of family member as a kind of risk that hit households lead them to expense more to manage risks, which effected household consumption and its variance.

The concept of Thailand to calculate the poverty group is most frequently use of poverty line as the cut off households, which stay below poverty line, are poor and the households, which stay upper poverty line, are not poor.

Therefore, poverty line measurement in Thailand based on the concept of physical subsistence is called the "absolute" approach. People are defined as poor if they do not have sufficient income to satisfy their basic needs. The poverty line defines the minimum basic needs of the people and is the threshold income below which one is considered to be poor (NSO, 1999).

The comparison of the household consumption with Thailand poverty line in the year of 2009, that was at 1,586 Baht per capita per month. The rural headcount ratio in terms of household expected consumption less than poverty line is relatively high at $65.8 \%$. When comparing by using regional poverty line of the northeast region of Thailand, which was at 1,473 Baht per capita per month. The percentage of expected consumption of household less than poverty line is still high at $63.4 \%$ (Table IV).

TABLE IV. COMPARISON OF EXPECTED CONSUMPTION AND POVERTY LINE
\begin{tabular}{|l|c|c|}
\hline \multicolumn{1}{|c|}{ Expected consumption } & Frequency & Percentage \\
\hline $\begin{array}{l}\text { Country poverty line in 2009 } \\
(1,586 \text { Baht per month per capita) }\end{array}$ & 273 & $65.80 \%$ \\
\hline $\begin{array}{l}\text { Expected consumption less than } \\
\text { poverty line }\end{array}$ & 142 & $34.20 \%$ \\
\hline $\begin{array}{l}\text { Expected consumption more than } \\
\text { poverty line }\end{array}$ & 263 & $63.40 \%$ \\
\hline $\begin{array}{l}\text { Northeastern poverty line in } \\
\text { 2009 } \\
(1,473 \text { Baht per month per capita) }\end{array}$ & 152 & $36.60 \%$ \\
\hline $\begin{array}{l}\text { Expected consumption less than } \\
\text { poverty line }\end{array}$ & 415 & 100 \\
\hline $\begin{array}{l}\text { Expected consumption more than } \\
\text { poverty line }\end{array}$ & & \\
\hline \multicolumn{2}{|c|}{ Total } & \\
\hline Source: Own calculation.
\end{tabular}

Poverty and vulnerability in Thailand arises as a result of transient rather than chronic conditions. The main causes of poverty were the lack of land ownership, lack of capital, education and skills, debts, irregular employment, large families, aging and sickness and uncontrollable outside forces (Taneerananon, 2005). This could be a result of chronic condition (e.g. low level of assets and endowments) or a transient situation (e.g. a temporary setback due to shocks). In term of vulnerability, the main causes are low expected consumption and high variance of consumption.

In order to provide policy advice, the literature of (e.g. Bidani and Richter, 2001) should be followed: the pool of 
vulnerable households are divided in two mutually-exclusive groups namely (1) those who are vulnerable due to the high volatility of their consumption or the HV vulnerable, and (2) those who are vulnerable due to their low expected mean consumption or the LM vulnerable (Alayande, 2004).

The result of this study shows two groups of vulnerable households, which are, high and low vulnerable households. The estimates show that about $44.34 \%$ of households were vulnerable to poverty (Table V).

TABLE V. COMPARISA ON OF OBSERVED POVERTY STATUS BASED ON VULNERABILITY INDEX

\begin{tabular}{|c|c|c|}
\hline Vulnerability households & Frequency & Percentage \\
\hline High vulnerability $>0.5$ & 184 & $44.34 \%$ \\
\hline Low vulnerability $<0.5$ & 231 & $55.66 \%$ \\
\hline Total & 415 & 100 \\
\hline
\end{tabular}

Source: Own calculation.

The comparison of observed poverty status based on vulnerability index present that $75.2 \%$ of farm households are poor, whereas another $24.8 \%$ are non-poor (Table VI).

TABLE VI. VULNERABILITY TO POVERTY HOUSEHOLD

\begin{tabular}{|c|c|c|}
\hline Poverty status & Frequency & Percentage \\
\hline Poor & 312 & $75.2 \%$ \\
\hline Non-Poor & 103 & $24.8 \%$ \\
\hline Total & 415 & 100 \\
\hline
\end{tabular}

Source: Own calculation.

Note: Poor $=$ Chronic poor + frequently poor + infrequently poor.

Chronic poor $=$ Chronic poor.

Transient poor $=$ Frequently poor + infrequently poor.

TABLE VII. COMPARISON OF VULNERABILITY TO POVERTY AND HOUSEHOLD DISTRICT ClASSIFIED BY NON-VULNERABLE AND

VulNerable Households In FReQueNCy AND PERCENTAGE OF POPULATION (PERCENTAGE IN ROW)

\begin{tabular}{|c|c|c|c|}
\hline & \multicolumn{3}{|c|}{ Percentage of population } \\
\hline & $\begin{array}{l}\text { Vulnerability } \\
\text { households }\end{array}$ & Non-vulnerable & Vulnerable \\
\hline & District & & \\
\hline 1 & Muang & 70.37 & 29.63 \\
\hline 2 & Lamphaimat & 65.79 & 34.21 \\
\hline 3 & Prakhonchai & 40.00 & 60.00 \\
\hline 4 & Satuk & 51.52 & 48.48 \\
\hline 5 & Krasang & 51.85 & 48.15 \\
\hline 6 & Nangrong & 52.00 & 48.00 \\
\hline 7 & Lahansai & 50.00 & 50.00 \\
\hline 8 & Bankruat & 45.00 & 55.00 \\
\hline 9 & Khu Mueong & 55.56 & 44.44 \\
\hline 10 & Nongki & 53.33 & 46.67 \\
\hline 11 & Phuthaisong & 53.33 & 46.67 \\
\hline 12 & Phlapphla Chai & 76.92 & 23.08 \\
\hline 13 & Nonghong & 46.15 & 53.85 \\
\hline 14 & Pakam & 76.92 & 23.08 \\
\hline 15 & Chaloemphrakiat & 53.85 & 46.15 \\
\hline 16 & $\mathrm{NaPho}$ & 45.45 & 54.55 \\
\hline 17 & Chamni & 33.33 & 66.67 \\
\hline 18 & Khaendong & 55.56 & 44.44 \\
\hline 19 & Banmaichaiyaphot & 50.00 & 50.00 \\
\hline 20 & Nondindaeng & 75.00 & 25.00 \\
\hline 21 & Non Suwan & 57.14 & 42.86 \\
\hline 22 & Huai Rat & 16.67 & 83.33 \\
\hline 23 & Ban Dan & 100.00 & 0.00 \\
\hline
\end{tabular}

Source: Own calculation.

Table VII presents the comparison of vulnerability to poverty and household district classified by non-vulnerable and vulnerable households. In overall number of households, non vulnerable households account for $55.66 \%$, the rest are vulnerable household account for $44.34 \%$. The comparison of non-vulnerable and vulnerable households, for example, Muang district has a higher percentage of non-vulnerable households than vulnerable households. On the other hand, for example, Huai Rat district has a very high percentage of vulnerable households.

\section{QUALITATIVE ANALYSIS ON INDIVIDUAL RISKS AND LIVELIHOOD STRATEGIES}

\section{A. Individual Risk}

There were more than one risk hit households in each period: last 5 years, last year and future. In this paper, last year risks are discussed. The analysis of risks show only the first risk refers most by households. The most occurred risks experienced by households during the last year are natural, physical and financial risks. Human and social risks are also rank in top ten risks as well.

Figure 3 showed the ranking of main experienced risks of farm household in last year (2009). Most risks hit households were drought, flood, crop loss from insect and plant disease, low price of production, crop loss from weather or natural disaster, heavy storm, local heavy rainfall, increasing of factor of production price, dread of working family member and unemployment. Most of risks are far beyond the ability of households to control them, for example, drought, and flood, which occurs frequently. Low price of production is as well, which depends on the demand and supply in the market. Production price is low because it is too much production supply in some seasons, high competition from the importing products and the middlemen or traders give the low price. Human and social risks that hit households are dread of working family member and unemployment. Other important risks are also important but those are not range in top ten risks hit household, are self-financed and credit-financed for the loss of crop and livestock, which cause the difficulties in many households. There are some households do nothing when the risks occurred because they do not have the ability to ask for the credit from any financial institution or no collateral assets and some of them fail on managing those risks again and again. Therefore, some households select no risks response.

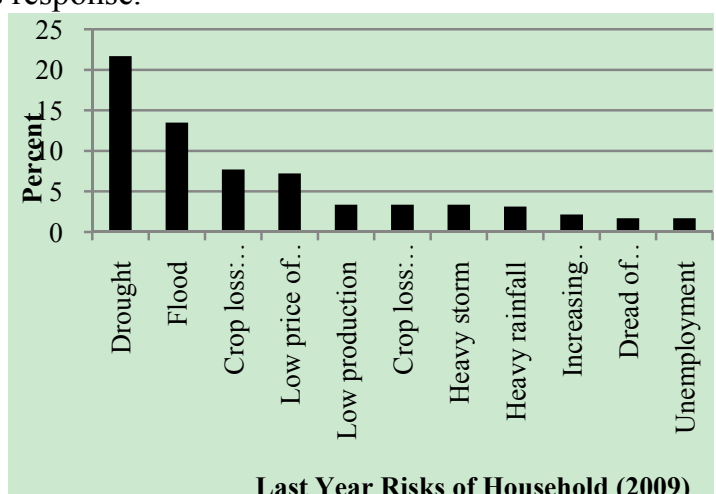

Fig. 3. Main risks of farm household in 2009. Source: Own calculation.

Each households face different risks. The risks that households encounter every year such as low production price, crop loss, and high factor cost of production, etc. Those are risks, which affect on agriculture work. After ranking the experienced risks, households are further 
indicating the level of the severity of the risks into five levels: very severe, severe, bad, not too bad and easy to recover. Most households present that the overall risks affect on them are very severe (Table VIII).

TABLE VIII. SEVERITY OF OVERALL RISKS

\begin{tabular}{|c|c|c|}
\hline Severity of risks & Frequency & Percent \\
\hline Highest or very severe & 146 & $\mathbf{3 5 . 1 8}$ \\
\hline High or severe & 65 & 15.66 \\
\hline Medium or bad & 73 & 17.59 \\
\hline Low or not too bad & 48 & 11.57 \\
\hline Lowest or easy to recover & 83 & 20.00 \\
\hline Total & 415 & 100 \\
\hline Source: Own calculation & & \\
\hline
\end{tabular}

\section{B. Livelihood Strategies}

The livelihood strategies are classified in adaptive strategies and coping strategies. According to adaptive strategies, most households were not preparing any strategies to manage on last year risk, accounted for $29.88 \%$. Households react not at all on the risk occurred because that risk occurs every year, like drought, and it is beyond their ability to control that situation.

Other adaptive strategies, which households prepare are ranked in orderly, which are saving in cash, hygiene and disease prevention, adoption of new production technology, ask for help from social network: relatives and friends, diversification of income sources, shifting cultivation, less risky production system, use of extension service, and saving in kind: live stocks.

Saving in cash is most selected because when households have saving, it is a guarantee for their wealth stability and they can run any activities related on their farm work or for any other purposes. Hygiene and disease prevention rank next important, which consistent to last year risk about the crop loss from insect and plant disease. Furthermore, household give the important on the adoption of new production technology because it can reduce time and energy on farm work. For example, the renting of tractors from village headman to harvest production can save the cost of labors and it is faster.

The coping strategies, which most households select to manage risks are reduced food consumption, credit from bank, dis-saving, take children out of school, sale of assets: crop, credit from money lender, pawned good, credit from family/relatives, new/additional work of other adult family member, and public assistance, respectively.

Reduced food consumption ranks first because it may easy to do for household. Asking credit from bank, especially, Bank of Agriculture and Cooperatives (BAAC), ranks secondly with $13.73 \%$. Dis-saving ranks third at $13.49 \%$. The next interesting category is take children out of school, account for $12.05 \%$. Some households think that school cost is so high and they want to cut the expenditure. The average education of family member is at primary school. Higher education study must spend a higher budget and most of them expect their children to help to work on farm in the future. Therefore, they think that high education is not needed (Table IX).
TABLE IX. LIVELIHOOD STRATEGIES IN 2009

\begin{tabular}{|c|c|c|c|}
\hline $\begin{array}{l}\text { Adaptive } \\
\text { strategies }\end{array}$ & Percent & Coping strategies & Percent \\
\hline React not at all & 29.88 & $\begin{array}{r}\text { Reduced food } \\
\text { consumption }\end{array}$ & 26.51 \\
\hline Saving in cash & 12.05 & Credit from bank & 13.73 \\
\hline $\begin{array}{l}\text { Hygiene and } \\
\text { disease } \\
\text { prevention }\end{array}$ & 11.57 & Dis-saving & 13.49 \\
\hline $\begin{array}{l}\text { Adoption of } \\
\text { new } \\
\text { production } \\
\text { technology }\end{array}$ & 9.40 & $\begin{array}{l}\text { Take children out } \\
\text { of school }\end{array}$ & 12.05 \\
\hline $\begin{array}{l}\text { Ask for help } \\
\text { from relatives } \\
\text { and friends }\end{array}$ & 8.19 & Sale of assets: crop & 6.02 \\
\hline $\begin{array}{l}\text { Diversification } \\
\text { of income } \\
\text { sources }\end{array}$ & 4.82 & $\begin{array}{l}\text { Credit from money } \\
\text { lender }\end{array}$ & 6.02 \\
\hline $\begin{array}{l}\text { Shifting } \\
\text { cultivation }\end{array}$ & 4.58 & Pawned good & 3.61 \\
\hline $\begin{array}{l}\text { Less risky } \\
\text { production } \\
\text { system }\end{array}$ & 4.10 & $\begin{array}{l}\text { Credit from } \\
\text { family/relatives }\end{array}$ & 3.37 \\
\hline $\begin{array}{l}\text { Use of } \\
\text { extension } \\
\text { service }\end{array}$ & 3.37 & $\begin{array}{l}\text { Additional work of } \\
\text { other adult family } \\
\text { member }\end{array}$ & 3.13 \\
\hline $\begin{array}{l}\text { Saving in } \\
\text { kind: } \\
\text { livestock }\end{array}$ & 2.65 & Public assistance & 2.41 \\
\hline
\end{tabular}

Source: Own calculation.

\section{CONCLUSIONS AND POLICY RECOMMENDATION}

Poverty is the unpleasant situation. In micro level, every household try to outreach the poverty status. However, it is not every household can be success to be far from poverty. In macro level, every governments attempt to promote the poverty attacking policy by creating several development projects and distributing budget and assistances to the target area. It is as same as micro level. It is not every project is successful.

The criticism is why households especially in the northeast and north still be poor shapely. On the other word, household in Bangkok, center, and south are stable. The cause of this comes from many reasons. For example, households in Bangkok and central regions are close to the center of development, market, financial, trading center and so on. Households in the south region have an abundance of natural resources, like mineral resources. Many provinces in the south gain benefit from a numerous of tourists. On the other hand, the north households are obstructed by the mountainous area, market access difficulties, cold and dry weather, etc. The northeast households are far from center, difficult to access to the market, encounter the problem of the dry soil, costly fuel cost, a numerous populations with large area to develop, etc. Therefore, the lack of natural resource, far distance from center, natural disaster, the change in economic structure and so on, is the fundamental causes of this region poverty.

The next criticism is why there are several projects implementation but local households still poor. It is as same as the word that "the entire road to Rome" and "everything at Bangkok". It seems that the direction of the development drawback to center. Most of development projects respondents are from the center. The benefit shares to those beneficiaries. The rest shares to target area. 
The direction of social and economic development plans of Thailand, which concentrates on the center, which incentive the huge inflow of budget, investment, development and civilization. Although the recent social and economic development plan attempt to decentralize policy and concentrate more on the distribution of income on other regions, but it looks like the half successful.

When analyzing into the detail of the development policy, there are many interesting points. The agricultural pricing and trade policies can help farmers from the price fluctuation. It needs a great amount of budget for the price support program. The result from the study (Table X) presents that farm household want government to help about the price guarantee on agricultural product. In fact, agricultural products are declining from many factors and it causes of low incentive to invest on the next crop production. Problem of agricultural works are mostly come from the natural disaster like heavy rainfall in rainy season and drought during summer. Another important problem is the insect attack on farm. Farmers are relying on the use of insecticide, which are very expensive while there is no any guarantee for the production price. It would be good if the policy run efficiently and can help farmers to solve this important problem.

The next policy that farm household raise is the financial aid or funding on farm work. High farm investment cost, low production and low production price lead to low income, it ends up with deficit. Farmers need funding aid to support farm work. In the agricultural development policy also have the provision of agricultural credit but the cause of farm work should be solve in parallel.

TABLE X. Household's Demand On Aiding Policy

\begin{tabular}{|c|c|c|c|c|}
\hline $\begin{array}{l}\text { Aiding policy for } \\
\text { household }\end{array}$ & Mean & $\begin{array}{c}\text { Std. } \\
\text { Deviation }\end{array}$ & Result & Rank \\
\hline $\begin{array}{l}\text { Agriculture } \\
\text { product price } \\
\text { guarantee or } \\
\text { crop insurance }\end{array}$ & 3.98 & 1.45 & High demand & 1 \\
\hline $\begin{array}{l}\text { Funding for } \\
\text { occupation }\end{array}$ & 3.97 & 1.37 & High demand & 2 \\
\hline $\begin{array}{l}\text { Fertilizer price } \\
\text { guarantee }\end{array}$ & 3.85 & 1.45 & High demand & 3 \\
\hline Job creation policy & 3.72 & 1.45 & High demand & 4 \\
\hline $\begin{array}{l}\text { Water supply for } \\
\text { agriculture }\end{array}$ & 3.65 & 1.58 & High demand & 5 \\
\hline $\begin{array}{l}\text { Circulate fund in } \\
\text { village }\end{array}$ & 3.64 & 1.54 & High demand & 6 \\
\hline Land ownership & 3.61 & 1.50 & High demand & 7 \\
\hline $\begin{array}{l}\text { Drug and gamble } \\
\text { reduction }\end{array}$ & 3.58 & 1.61 & High demand & 8 \\
\hline $\begin{array}{l}\text { Construction of } \\
\text { concrete road to } \\
\text { village }\end{array}$ & 3.44 & 1.62 & High demand & 9 \\
\hline
\end{tabular}

Demand on fertilizer price guarantee rank third category. It is certainly that fertilizer price play an important role on agricultural work. Production function is determined by the factor demand. By the way, the input supply and input price are fluctuating. Farmers take a very high risk of lacking input supply and the risk of increasing input price. Nowadays, farmers put high chemical on farm. Government should promote farmers to use organic fertilizer and support a certain cost of fertilizer and insecticide.

Water supply for agriculture is also important because lack of water, it is hardly to plant any crop. At the research area in Buri Ram province encounter of the drought occurrence every year. For the agricultural development policy, approximately 60 percent of the annual agricultural budget has been allocated for the development of irrigation aimed to increase productivities. Presently, only 20 percent of the total arable lands are irrigated. It will be advantaged for the farm households if the irrigated system can be expanded to all arable area. The discussion about the policy is the direction of budget spending from the past (half century) invest a lot on irrigation project; it is hard to expand the irrigation area cover 100 percent of the total arable land. It's the time of discussing about the cost and benefit analysis that the target group receive.

The next demand is the demand on funding circulates in village. At present, Thailand has National Village and Urban Community Fund, which provide the micro credit to all villages in Thailand. The benefits of this project are the increasing in the income distribution of Thailand, the increasing economic growth, and the solving poverty problem. On the opposition, the negative effects are the result of lacking financial discipline. Some households have too much expenditure, consumption and debt. However, there are many reports conclude that this projects have positive effect than the negative result, so this project still ongoing until now.

The last point is the demand on land allocation. Farmers need their own farm land because some farmers must pay for the high rent cost. Some must do the farm on other farm land and get only the hiring wage. It is uncertainly for the cash flow to sustain their living. For the agricultural land reform policy, which aims to redistribute farm land and enhance agricultural land-use efficiency. At present, it still continues. It would be better if farm households can reduce farm rent cost, have their own farm, and not invade the forest. However, this policy is complicated because it involves a lot of beneficiaries, especially politician.

\section{ACKNOWLEDGMENT}

First and foremost, I would like to express a special thank to Prof. Dr. Gertrud Buchenrieder who is encouraging me to continue this research. Furthermore, I would like to give many thanks to Faculty of Management Science, Khon Kaen University, which was generous to provide the necessary funding for the empirical research in Thailand.

\section{REFERENCES}

[1] A. D. Oduro., K. Appiah-Kubi, and B.Senadza, "Understanding Poverty in Ghana: Risk and Vulnerability," in Proc. The International Conference on Ghana at the Half Century in Accra at Import Plaza Hotel, on 18-20 July 2004, Ghana, 2004.

[2] A. Suryahdi, and S. Sumarto, "The Chronic Poor, the Transient Poor and the Vulnerable Group in Indonesia, Before and After the Crisis". Jakarta, Indonesia: The SMERU Research Institute, pp.1-28, May 2001.

[3] B. Alayande, and O. Alayande, "A Quantitative and Qualitative Assessment of Vulnerability to Poverty in Nigeria," Paper Prepared for CSAE Conference on Poverty Reduction, Growth and Human Development in Africa, 2004..

[4] B. Bidani, and K. Richter, "Household Vulnerability and the Asian Crisis: The Case of Thailand," World Bank, 2001. 
[5] E. Ligon, and L. Schechter, "Measuring Vulnerability," Research Paper No.2002/86, World Institute for Development Economics Research: WIDER, pp. 1-24, 2002.

[6] E.D.Tesliuc, and K. Lindert, "Vulnerability: A Quantitative and Qualitative Assessment," World Bank: Guatemala poverty Assessment Program, pp.1-91, 2002

[7] G. Mansuri, and A. Healy, "Assessing Vulnerability: An Ex ante Measure and its Application Using Data from Rural Pakistan," Washington, D.C., USA: World Bank: Development Research Group, 2000 .

[8] I.B. Oluwatayo, "Income Risk and Welfare Status of Rural Households in Nigeria". Research Paper No.2004/61, World Institute for Development Economics Research: WIDER, pp. 1-18, 2004.

[9] J. Jalan, and R. Martin, "Estimating the Benefit Incidence of An Antipoverty Program By Propensity-Score Matching," Journal of Business and Economic Statistics, American Statistical Association, vol. 21, no.1, pp. 19-30, January, 2003.

[10] NESDB, (2008). "Data and Indicator of Poverty and Income Distribution (1988-2008)". Thailand: National Economic and Social Development Board (NESDB). [Online]. Available at: http://poverty.nesdb.go.th.

[11] NSO, (2007). "Average Monthly Income per Household by Source of Income and Province in 2007". Bangkok, Thailand: National Statistics Office. [Online]. Available: service.nso.go.th/nso/nsopublish/service/survey/socioIncome_50.xls.

[12] S. Chaudhuri, "Empirical Methods for Assessing Household Vulnerability to Poverty," New York, USA: Columbia University, 2000.

[13] S. Chaudhuri, and G. Datt, "Assessing Household Vulnerability to Poverty: A Methodology and Estimates for the Philippines," Washington, DC., USA: World Bank, 2001.

[14] S. Chaudhuri, J. Jalan, and A. Suryahadi, "Assessing Household Vulnerability to Poverty from Cross-sectional Data: A Methodology and Estimates from Indonesia," Discussion Paper No. 0102-52. New York, USA: Columbia University, Department of Economics, 2002.
[15] S. Dercon, (August 2001). Income Risk, Coping Strategies and Safety nets, The Centre for the Study of African Economies Working Paper, CSAE WPS/2003-01. [Online]. pp.1-36. Oxford University, Department of Economics. Available: http://www.wiwiss.fu-berlin.de/w3/w3 collie/SocPolWS03/DerconSur vey.pdf.

[16] S. Taneerananon, "Demographic Behaviour Responses to Poverty: Findings from the Participatory Poverty Assessment of Thailand," In Proc. IUSSP XXV International Population Conference,Tours, France, 18-23 July 2005, pp.1-4.

[17] The Economist, (April 20, 2011). "Income Equality". [Online]. Available: http://www.economist.com/node/18587127.

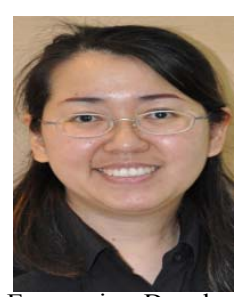

Thitiwan Sricharoen, Assistant Professor of Economics at Faculty of Management Science, Khon Kaen University, Thailand. Born in Chonburi in 1974. Educational Qualification: B.A. (Economics) in 1996 from Thammasat University, Thailand, M.A. (Economics) in 1998 from Chulalongkorn University, Thailand, Ph.D. (Agricultural Economics) in 2007 from University of Hohenheim, Germany. Her field of specialization is International conomics, Development Economics and Agricultural Economics.

She has more than 11 years of teaching and research experience. She is the author of books of International Trade Theory and Policy, Khon Kaen: Khon Kaen University, 2011. She has also published many research papers and articles in different national and international journals. She has presented papers in national and international conference, i.e. Germany, Switzerland, Singapore and Hong Kong.

Dr. Sricharoen also works for Graduate School, Khon Kaen University, Thailand. She has developed a number of graduate level courses. 